Annals of International Medical and Dental Research

E-ISSN: 2395-2822 | P-ISSN: 2395-2814

Vol-8, Issue-2 | March-April 2022

DOI: 10.53339/aimdr.2022.8.2.22

Page no- 164-173 | Section- Research Article (Orthopedics)

\title{
Determinants of Observance to Osteoporosis Treatment in Clinical Practice in a Single Center Study
}

\section{Ehteshamul Haque ${ }^{*}$, Homayera Rahman ${ }^{2}$, Md Mobaraque Hossain Khan $^{3}$, Sayeda Niger Sultana ${ }^{4}$}

${ }^{1}$ Assistant Professor, Department of Orthopedics, CARe Medical College, Dhaka, Bangladesh.

Email: drehtesham_123@yahoo.com, Orcid ID: 0000-0003-3885-6122.

2Professor, Department of Physiology, Greenlife Medical College, Dhaka, Bangladesh.

Email: drhomayera@yahoo.com, Orcid ID: 0000-0002-9029-8132

${ }^{3}$ Assistant professor, Department of Othopaedic, Shaheed Tajuddin Ahmad Medical College Hospital, Gazipur, Bangladesh.

Email: mailto:khanmobaraque811@gmail.com Orcid ID: 0000-0001-6411-6721

${ }^{4}$ Assistant Professor, Department of obstetrics and gynaecology, Prime Medical College, Rangpur, Bangladesh. Email: nigern37@gmail.com,

Orcid ID: 0000-0002-6243-4061

*Corresponding author

Received: 15 December 2021

Revised: 27 January 2022

Accepted: 07 February 2022

Published: 18 February 2022

\begin{abstract}
Background: Improve compliance to prescribed medications is common in clinical practice, and it can lead to potentially fatal outcomes. This continues to be a common issue in the treatment of osteoporosis, although the causes of discontinuation and low compliance are complicated and understudied. Material \& Methods: A survey was conducted in 101 patients at Narsingdi Sadar Hospital, Narsingdi, Dhaka, Bangladesh for osteoporosis management for a follow-up assessment, one year (July 2020 to June 2021) after having been prescribed a treatment with one of the following drugs: Calcium+vitamin D supplements alone (CaVitD), hormone replacement therapy (HRT), risedronate $5 \mathrm{mg} /$ day (RIS), alendronate (ALN OW), Ibandronic acid monthly and Zolindronic acid I/V inj yearly. Results: Overall, $19.1 \%$ stopped taking their prescribed medication before their bone mass reevaluations, with more than half of them doing so within the first 6 months. The dropout rate differed dramatically between regimens. ALNOW was by far the least interrupted (6.9\%; p0.001 versus any other treatment). The most common causes for cessation were drug-related side effects, a lack of willingness to continue therapy, and a fear of negative effects. The reasons for discontinuation differed by treatment: safety concerns were very common for HRT, lack of motivation was the most common cause for $\mathrm{CaVitD}$ and drug-related side effects were the most common cause for RIS, ALN, Ibandronic acid and Zolindronic acid . Patients having a history of vertebral fractures, densito-metric osteoporosis, or who were using corticosteroid or anti-inflammatory medications had a considerably greater rate of treatment adherence. Patients on benzodiazepine or gastroprotective drugs, as well as those for whom a bone measurement was not easily accessible, had a considerably greater probability of treatment interruption. ALN OW and HRT had the highest compliance to recommended dosing (p0.001 versus any other) and CaVitD had the lowest ( $\mathrm{p} 0.01$ versus any other). Poor treatment compliance (50 percent medicine taken) was strongly associated with benzodiazepine and gastroprotective usage, whereas significantly higher compliance was associated with established osteoporosis risk factors: early menopause, low bone mass values, and past vertebral fractures. Adherence was lowest when treatments were prescribed by general practitioners (GPs) and orthopaedic surgeons (p0.01 compared to the global mean). Conclusions: According to the conclusions of this large survey of Bangladeshi osteoporotic women, the kind of medicine provided is the most important factor of both persistence
\end{abstract}


Annals of International Medical and Dental Research

E-ISSN: 2395-2822 | P-ISSN: 2395-2814

Vol-8, Issue-2 | March-April 2022

DOI: 10.53339/aimdr.2022.8.2.22

Page no- 164-173 | Section- Research Article (Orthopedics)

and compliance to treatment, with ALN-OW having a separate advantage. Treatment is particularly low for CaVitD, suggesting the need for innovative methods of supplementing at least vitamin D. The most common causes for cessation include adverse effects and a lack of motivation, while patients with severe and well-documented osteoporosis would have the maximum medication compliance.

Keywords:- Observance, Adherence, Compliance, Osteoporosis, Persistence, Treatment.

\section{INTRODUCTION}

Poor adherence to prescribed treatments is widespread in clinical practice, with reported rates close to $50 \%$, particularly for many chronic conditions considered "clinically silent" to the patient. $[1,2,3]$ This can lead to potentially life-threatening events. $[4,5,6,7]$ Evidence is accumulating which demonstrates that a substantial proportion of patients abandon current osteoporosis treatments within just 6-7 months of treatment initiation and that the probability of continuing osteoporosis treatment decreases over time. $[8,9,10,11]$ The proportion of patients with un-interrupted therapy after 1 year was found to be close to only $20 \%$ for any type of antiresorptive therapy.[12] Compliance to prescribed dosing, generally continuing how well a patient follows a physician's instructions during a specific period, is also often inadequate.[13] It has been recognized that the full benefits of medications for osteoporosis cannot be reached if compliance is low. Poorly compliant patients have smaller bone mineral density (BMD) gains, a weaker suppression of bone turnover and, ultimately, a greater risk for fractures than patients who adhere to their prescribed therapy.[14,15] The causes of discontinuation and low compliance to medical therapy for osteoporosis in patients treated in clinical practice are complex and poorly defined, and the rates of both are likely to be worse than those reported in patients participating in clinical trials, where the latter are probably healthier and better counselled than patients in clinical practice.

We report here the rate and possible determinants of poor adherence (persistence and compliance) to osteoporosis treatment in a large number of women prescribed a pharmacological treatment for osteoporosis in a routine clinical setting. The term adherence comprises here both compliance and persistence to treatment. Compliance refers to how the medication is taken or quality of intake. Persistence is defined as the time from initiation to discontinuation of treatment.

\section{MATERIAL AND METHODS}

During a 1 year period the hospital were asked to recruit into the study all consecutive postmenopausal women referred for a control of bone mass who had been prescribed at least 1 year prior to this time one of the pharmacological agents registered for the treatment of osteoporosis in Narsingdi Sadar Hospital, Narsingdi, Bangladesh. After obtaining an informed consent approved by each ethical committee, the patients were asked to complete a questionnaire. The data were 
Annals of International Medical and Dental Research

E-ISSN: 2395-2822 | P-ISSN: 2395-2814

Vol-8, Issue-2 | March-April 2022

DOI: 10.53339/aimdr.2022.8.2.22

Page no- 164-173 | Section- Research Article (Orthopedics)

then collected on a specific data collection form or directly on an electronic grid that allowed an initial automatic cleaning of the data by flagging any outliner value. The data were then sent electronically to a web center, which was accessible to all investigators throughout the study period and which is currently accessible to any qualified medical doctor. The patients' demographic and reproductive characteristics recorded at baseline were: age, weight, height, age at menopause, type of menopause (natural, surgical). In addition, details about the following clinical and lifestyle risk factors were collected: history of fragility fractures after age 40 years, history of fragility hip fracture in mother, problems with sense organs (sight, hearing), smoking status, alcohol consumption, regular exercise and mobility status. The presence of concurrent diseases that may increase the risk of osteoporosis or falls was recorded. The following information was obtained on the osteoporosis treatment prescribed at the previous visit: type of drug, specialization of the prescribing doctor, degree of compliance, time and reasons of incidental discontinuation. Given the nature of the study, the data on treatment adherence were exclusively self-reported. The SPSS ver. 24.0 statistical software programme (SPSS,Chicago, Ill.) was used for all statistical analyses. The between-groups differences were analyzed by repeated measures analysis of variance (ANOVA) or by co-variance analyses and then by t-test, with the Bonferroni comparison test applied for multiple comparisons. Logistic regression analysis was used for analyzing the Relative Risk (RR) for treatment discontinuation. Analyses for categorical data related to treatment compliance was performed using the $x^{2}$-test.

\section{RESULTS}

Overall, $19.1 \%$ stopped taking their prescribed medication before their bone mass reevaluations, with more than half of them doing so within the first 6 months. The dropout rate differed dramatically between regimens. ALN-OW was by far the least interrupted (6.9 \%; p0.001 versus any other treatment). The most common causes for cessation were drug-related side effects, a lack of willingness to continue therapy, and a fear of negative effects. The reasons for discontinuation differed by treatment: safety concerns were very common for HRT, lack of motivation was the most common cause for CaVitD, and drug-related side effects were the most common cause for RIS, ALN, and Alandronic acid and Zolindronates. Patients having a history of vertebral fractures, densitometric osteoporosis, or who were using corticosteroid or anti-inflammatory medications had a considerably greater rate of treatment adherence. Patients on benzodiazepine or gastro protective drugs, as well as those for whom a bone measurement was not easily accessible, had a considerably greater probability of treatment interruption. ALN OW and HRT had the highest compliance to recommended dosing (p0.001 versus any other) and CaVitD had the lowest (p0.01 versus any other). Poor treatment compliance (50 percent medicine taken) was strongly associated with benzodiazepine and gastro protective usage, whereas significantly higher compliance was associated with established osteoporosis risk factors: early menopause, low bone mass values, and past vertebral fractures. Observence was lowest when treatments were prescribed by general practitioners (GPs) and 
Annals of International Medical and Dental Research

E-ISSN: 2395-2822 | P-ISSN: 2395-2814

Vol-8, Issue-2 | March-April 2022

DOI: 10.53339/aimdr.2022.8.2.22

Page no- 164-173 | Section- Research Article (Orthopedics)

Orthopaedic surgeons (p0.01 compared to the

global mean).

Table 1: Referring specialists and the treatment prescribed (percentage by each specialist) for osteoporosis, Number of patients Calcium-vitamin D, Hormones, Alendronate, Risedronate, Ibandronic acid and Zolindronic acid.

\begin{tabular}{|l|l|l|l|l|l|l|l|}
\hline & $\begin{array}{c}\text { Number } \\
\text { of } \\
\text { patients }\end{array}$ & $\begin{array}{c}\text { Calcium- } \\
\text { vitamin } \\
\text { D }\end{array}$ & Hormones & $\begin{array}{c}\text { Ibandronic } \\
\text { acid }\end{array}$ & $\begin{array}{c}\text { Zolindronic } \\
\text { acid I/V } \\
\text { (inj) }\end{array}$ & Alendronate & Risedronate \\
\hline Endocrinologist & 8 & $18.2 \%$ & $4.9 \%$ & $12.8 \%$ & $13.2 \%$ & $40.2 \%$ & $10.7 \%$ \\
\hline Physiatrist & 7 & $14.2 \%$ & $0.4 \%$ & $6.4 \%$ & $12.6 \%$ & $55.0 \%$ & $11.4 \%$ \\
\hline Geriatrician & 8 & $9.6 \%$ & $0.8 \%$ & $9.3 \%$ & $12.2 \%$ & $53.2 \%$ & $14.8 \%$ \\
\hline Gynecologist & 15 & $11.1 \%$ & $51.0 \%$ & $16.2 \%$ & $4.2 \%$ & $14.5 \%$ & $3.0 \%$ \\
\hline Internist & 11 & $11.8 \%$ & $1.2 \%$ & $6.3 \%$ & $12.0 \%$ & $57.8 \%$ & $10.8 \%$ \\
\hline $\begin{array}{l}\text { General } \\
\text { practitione }\end{array}$ & 17 & $31.0 \%$ & $0.5 \%$ & $4.0 \%$ & $35.0 \%$ & $24.7 \%$ & $4.8 \%$ \\
\hline $\begin{array}{l}\text { Orthopedic } \\
\text { surgeon }\end{array}$ & 16 & $16.5 \%$ & $0.4 \%$ & $5.7 \%$ & $25.0 \%$ & $40.8 \%$ & $11.5 \%$ \\
\hline Rheumatologist & 14 & $15.6 \%$ & $0.8 \%$ & $5.9 \%$ & $15.1 \%$ & $49.6 \%$ & $13.0 \%$ \\
\hline Others or mix & 5 & $2.4 \%$ & $3.8 \%$ & $7.8 \%$ & $17.8 \%$ & $59.1 \%$ & $12.0 \%$ \\
\hline All & 101 & $17.1 \%$ & $8.1 \%$ & $7.9 \%$ & $17.7 \%$ & $29.8 \%$ & $9.5 \%$ \\
\hline
\end{tabular}

Table 2: Baseline characteristics of the study population according to the assigned treatment: mean and standard deviation (SD).

\begin{tabular}{|c|c|c|c|c|c|c|}
\hline Treatment & $\begin{array}{c}\text { Age } \\
\text { (years) }\end{array}$ & $\begin{array}{c}\text { Age of } \\
\text { menopause } \\
\text { (years) }\end{array}$ & BMI(kg/m2) & $\begin{array}{c}\text { BMD } \\
\text { spine } \\
\text { (T-score) }\end{array}$ & $\begin{array}{c}\text { BMD } \\
\text { total hip } \\
\text { (T-score) }\end{array}$ & $\begin{array}{c}\text { Stiffness } \\
\text { QUSCalcaneous(T- } \\
\text { score) }\end{array}$ \\
\hline Calcium-vitamin D $(\mathrm{n}=17)$ & $\begin{array}{l}63 \\
(10) *\end{array}$ & $48(5)$ & $26.2(4.5)^{*}$ & $\begin{array}{l}-2.1 \\
(1.1)^{*}\end{array}$ & $\begin{array}{l}-1.9 \\
(0.9)^{*}\end{array}$ & $-2.0(1.1)^{*}$ \\
\hline $\begin{array}{ll}\begin{array}{l}\text { Hormone } \\
\text { therapy }(\mathrm{n}=8)\end{array} & \text { replacement } \\
\end{array}$ & $55(6)^{*}$ & $47(6)$ & $24.4(3.7)^{*}$ & $\begin{array}{l}-1.7 \\
(1.3)^{*}\end{array}$ & $\begin{array}{l}-1.2 \\
(1.2)^{*}\end{array}$ & $-1.4(0.8)^{*}$ \\
\hline Ibandronic Acid $(\mathrm{n}=8)$ & $60(8)^{*}$ & $48(6)$ & $25.0(4.0)$ & $\begin{array}{l}-2.7 \\
(0.9)\end{array}$ & $\begin{array}{l}-2.3 \\
(0.9)\end{array}$ & $-2.4(1.1)^{*}$ \\
\hline $\begin{array}{l}\begin{array}{l}\text { ZolindronicAcid } \\
(\mathrm{n}=17)\end{array} \\
\text { /V inj }\end{array}$ & $67(8)$ & $48(5)$ & $25.7(4.3)$ & $\begin{array}{l}-2.8 \\
(1.1)\end{array}$ & $\begin{array}{l}-2.4 \\
(1.1)\end{array}$ & $-2.8(1.1$ \\
\hline $\begin{array}{l}\text { Alendronate } 10 \mathrm{mg} \text { daily }(\mathrm{n}= \\
\text { 17) }\end{array}$ & $67(8)$ & $48(5)$ & $25.3(4.0)$ & $\begin{array}{l}-2.9 \\
(1.1)\end{array}$ & $\begin{array}{l}-2.4 \\
(1.1)\end{array}$ & $-3.4(1.1)$ \\
\hline $\begin{array}{l}\text { Alendronate } 70 \mathrm{mg} \text { weekly } \\
(\mathrm{n}=22)\end{array}$ & $66(9)$ & $48(5)$ & $25.7(4.3$ & $\begin{array}{l}-2.8 \\
(1.0)\end{array}$ & $\begin{array}{l}-2.4 \\
(1.0)\end{array}$ & $-3.1(1.0)$ \\
\hline Risendronate $(\mathrm{n}=9)$ & $67(9)$ & $48(5)$ & $25.5(4.2)$ & $\begin{array}{l}-2.9 \\
(1.0)\end{array}$ & $\begin{array}{l}-2.4 \\
(1.1)\end{array}$ & $-3.0(0.9)$ \\
\hline Total $(n=101)$ & $64(9)$ & $48(5)$ & $25.5(4.2)$ & $\begin{array}{l}-2.6 \\
(1.2)\end{array}$ & $\begin{array}{l}-2.2 \\
(1.1)\end{array}$ & $-2.7(1.2)$ \\
\hline
\end{tabular}

${ }^{*} \mathrm{p}<0.05$ between groups 
Annals of International Medical and Dental Research

E-ISSN: 2395-2822 | P-ISSN: 2395-2814

Vol-8, Issue-2 | March-April 2022

DOI: $10.53339 /$ aimdr.2022.8.2.22

Page no- 164-173 | Section- Research Article (Orthopedics)

Table 3: Treatment discontinuation

\begin{tabular}{|c|c|c|c|c|c|c|c|c|}
\hline & CalciumvitamiD & HRT & $\begin{array}{c}\text { Ibandronic } \\
\text { Acid } \\
\text { Monthly } \\
\end{array}$ & $\begin{array}{l}\text { Zolindronic } \\
\text { Acid I/V } \\
\text { inj/Yearly }\end{array}$ & $\begin{array}{c}\text { Alendronate } \\
\text { daily }\end{array}$ & $\begin{array}{c}\text { Alendronate } \\
\text { weekly }\end{array}$ & $\begin{array}{c}\text { Risedronate } \\
\text { daily }\end{array}$ & Total \\
\hline $\begin{array}{l}\text { Within6 } \\
\text { months }\end{array}$ & $14(14.3)$ & $\begin{array}{l}56 \\
(7.0)\end{array}$ & $71(9.1)$ & $236(13.6)$ & $16(79.8)$ & $131(5.9)$ & $110(11.8)$ & $\begin{array}{l}1012 \\
(10.3)\end{array}$ \\
\hline $\begin{array}{l}6-12 \\
\text { months }\end{array}$ & $9(5.4)$ & $\begin{array}{l}27 \\
(3.4) \\
\end{array}$ & $41(5.3)$ & $141(8.2)$ & $113(6.6)$ & $19(0.9)$ & $44(4.7)$ & $\begin{array}{l}476 \\
(4.8 \\
\end{array}$ \\
\hline $\begin{array}{l}\text { After12 } \\
\text { months }\end{array}$ & $3(2.9)$ & $\begin{array}{l}100 \\
(12.6)\end{array}$ & $15(1.9)$ & $122(14.2)$ & $76(4.5)$ & $4(0.1)$ & $23(2.5)$ & $\begin{array}{l}389 \\
(3.1)\end{array}$ \\
\hline Total & $(22.7)$ & $\begin{array}{l}183 \\
(23.0)\end{array}$ & $127(16.3)$ & $499(28.7)$ & $356(20.9)$ & $154(6.9)$ & $177(19.0)$ & $\begin{array}{l}1877 \\
(19.1)\end{array}$ \\
\hline
\end{tabular}

aValues are the number of patients who discontinued the treatment; the corresponding percentage is given in parenthesis

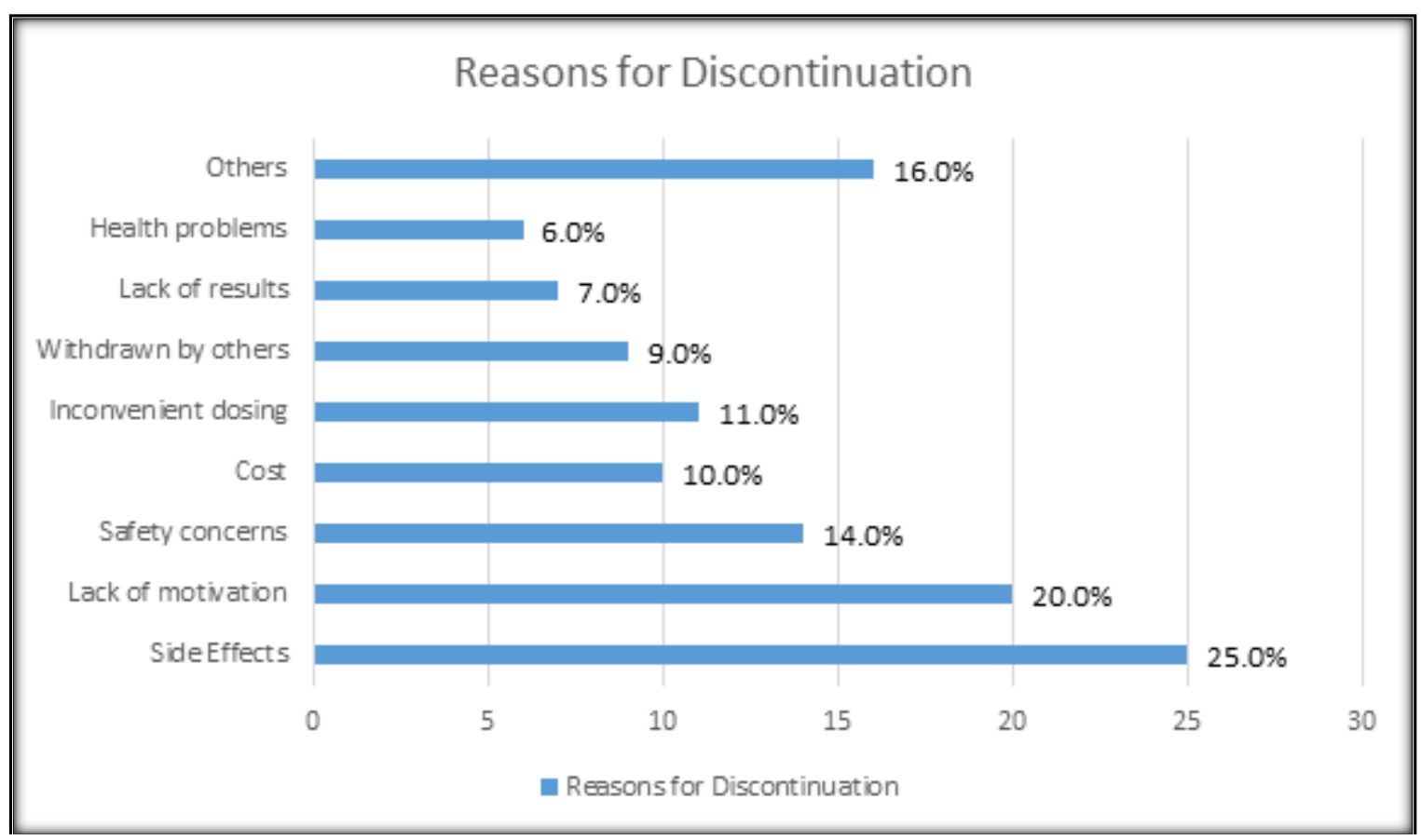

Figure 1: Reasons for Discontinuation

Table 4: Compliance to

\begin{tabular}{|l|l|l|l|l|l|l|l|l|}
\hline & $\begin{array}{c}\text { Calciumvitamin } \\
\mathbf{D}(\boldsymbol{\%})\end{array}$ & $\begin{array}{l}\text { HRT } \\
(\boldsymbol{\%})\end{array}$ & $\begin{array}{l}\text { Ibandronic } \\
\text { Acid }\end{array}$ & $\begin{array}{l}\text { Zolindronic } \\
\text { Acid I/V inj }\end{array}$ & $\begin{array}{c}\text { Alendronate } \\
\text { daily }(\boldsymbol{\%})\end{array}$ & $\begin{array}{c}\text { Alendronate } \\
\text { weekly (\%) }\end{array}$ & $\begin{array}{c}\text { Risedronate } \\
\text { daily }(\boldsymbol{\%})\end{array}$ & $\begin{array}{c}\text { Total } \\
(\boldsymbol{\%})\end{array}$ \\
\hline$<30 \%$ & 7.0 & 1.2 & 2.4 & 3.7 & 2.6 & 1.3 & 2.3 & 3.1 \\
\hline $30-50 \%$ & 14.0 & 1.4 & 4.7 & 8.7 & 6.8 & 1.6 & 5.0 & 6.4 \\
\hline $50-80 \%$ & 26.8 & 7.8 & 15.5 & 27.1 & 21.9 & 12.7 & 18.7 & 19.7 \\
\hline
\end{tabular}

aValues are given as a percentage within each treatment 
Annals of International Medical and Dental Research

E-ISSN: 2395-2822 | P-ISSN: 2395-2814

Vol-8, Issue-2 | March-April 2022

DOI: 10.53339/aimdr.2022.8.2.22

Page no- 164-173 | Section- Research Article (Orthopedics)

Table 5: Medical history and relative risk (RR) of discontinuation or low compliance $(<50 \%$ drug taken). Multiple logistic regressionanalysis with data adjusted for treatment type

\begin{tabular}{|l|l|l|l|}
\hline \multicolumn{1}{|c|}{ Variables } & \multicolumn{1}{|c|}{$\mathbf{n}(\boldsymbol{\%})$} & $\begin{array}{c}\text { RR for discontinuation } \\
\mathbf{5 - 9 5 \%} \text { confidence interval }\end{array}$ & \multicolumn{1}{|c|}{$\begin{array}{c}\text { RR for low compliance } \\
\mathbf{5}-\mathbf{9 5 \%} \text { confidence interval }\end{array}$} \\
\hline Early menopause & $(21.9$ & $1.080(96-1.23)$ & $0.83^{*}(0.73-0.95)$ \\
\hline Family history for osteoporosis & $(13.3)$ & $0.950(82-1.10)$ & $0.75^{*}(0.48-0.98)$ \\
\hline Prevalent spine fracture & $(17.3)$ & $0.64^{*}(0.43-0.82)$ & $0.70^{*}(0.61-0.80)$ \\
\hline Bone measure not readily available & $(20.6)$ & $1.28^{*}(1.05-1.59)$ & $1.51^{*}(1.22-1.85)$ \\
\hline Osteoporosis (T-score <-2.5) & $(43.7)$ & $0.68^{*}(0.56-0.82)$ & $0.74^{*}(0.62-0.88)$ \\
\hline Corticosteroid therapy & $(6.5)$ & $0.69^{*}(0.37-0.95)$ & $0.82(0.66-1.01)$ \\
\hline Anti-inflammatory therapy & $(14.3)$ & $0.84^{*}(0.65-0.99)$ & $0.92(0.80-1.06)$ \\
\hline Benzodiazepin treatment & $(6.5)$ & $1.36^{*}(1.23-1.45)$ & $1.12(0.92-1.36)$ \\
\hline Gastro-protection therapy & $(11.0)$ & $1.24^{*}(1.11-1.34)$ & $1.17^{*}(1.00-1.37)$ \\
\hline
\end{tabular}

\section{DISCUSSION}

This is the largest survey to date that has been carried on treatment adherence to osteoporosis treatment. The mean discontinuation rate was $19 \%$, the same proportion as that observed by Tosteson but over a mean period of follow up of only 7 months rather than the 14 months of our study. ${ }^{[8]}$ The treatment persistence we observed may have been overestimated because the discontinuation rate is likely to be higher in the unknown number of patients who had a prescription 1 year prior to the beginning of our study but who did not return for follow-up. Both compliance and persistence were self-reported in the present study and not verified by objective tools. This may also be a source of overestimation of global adherence. In addition, our results are applicable only to patients in whom the osteoporosis treatment was prescribed on the basis of a densitometric evaluation. In a setting comparable to ours, $90.3 \%$ of the patients were still taking cyclical etidronate (Bisphosphonate) after 1 year, compared to $77.6 \%$ for once-daily doses of alendronate. [16] In studies carried out from data derived by health insurance or administrative databases, adherence to treatment has been found to be considerably lower, ranging from 25 to $50 \% .[12,17,18,19,20]$ In general, treatment discontinuation rate varies considerably with type of treatment. In our series, the treatment adherence to HRT was at least twofold greater than that observed in other studies.[17,21,22] However, in these latter studies HRT was primarily prescribed to relieve the acute symptoms of menopause, even after screening patients for a recorded diagnosis for osteoporosis. This was not likely to be the case in our patients in whom the main motivation to treatment was the presence of osteoporosis.

The poorest performance was observed for intravenous Zolindronic acid, which in Bangladesh is registered but reimbursed lately for the treatment of osteoporosis, allegedly for lack of evidence of anti-fracture efficacy. This type of treatment is not extensively prescribed by GPs, perhaps for its high cost. However, this suggests a different approach between physicians and different specialties in how patients are educated and treated. The discontinuation rate for the other drugs was very similar, with the only remarkable 
Annals of International Medical and Dental Research

E-ISSN: 2395-2822 | P-ISSN: 2395-2814

Vol-8, Issue-2 | March-April 2022

DOI: 10.53339/aimdr.2022.8.2.22

Page no- 164-173 | Section- Research Article (Orthopedics)

exception being ALN OW which showed a treatment persistence rate threefold higher than that of any other treatment. It has been shown that treatment adherence improves as the number of doses taken each day decreases,[23] and with weekly versus daily regimens. $[20,24,25,26]$ Our results also provide further evidence that in comparison to daily dosing weekly dosing does improve persistence to treatment not only during controlled clinical trials but also in routine clinical practice. The most common reasons for treatment discontinuation were the appearance of side effects, which accounted for a quarter of all cases. This proportion is considerably lower than the $80 \%$ reported by Tosteson et al.[8] However, our questionnaire provided patients a broader range of possible causes than did that of Tosteson et al., including cost, inconvenient dosing, advice from other specialists, and these alternatives were frequently chosen by patients. One should recognize that the causes of inadequate treatment adherence may differ considerably depending on cultural and economic conditions. For example, lack of motivation may largely depend on the prestige of the prescriber or on the clinical relevance attributed to the disease under different cultural conditions. Thus, Zolindronic Acid, which was a little prescribed by only specialist not GPs, was discontinued first for lack of motivation and only thereafter for the inconveniencies related to the intravenous administration. Cost may be a problem when the drug is not reimbursed early previous days. This was the case for ALN, RIS and Ibandronic acid when prescribed to patients without previous osteoporotic fractures or for not all treated patients. The main reason of discontinuation of HRT was the fear of side effects, since the study was carried out at the time of the first media reports on the results of the Women's Health Initiative study.[27] Daily dosing with RIS and ALN, with their complex dosing instructions, were initially considered by several patients to be inconvenient and then often discontinued. This cause of discontinuation was, however, possibly also driven by the advertised availability of the weekly formulation of ALN. An important strength of our study is the possibility of identifying the risk factors for treatment discontinuation. Persistence to treatment was strongly related to factors that are likely to increase treatment motivation, such as: previous vertebral fractures, corticosteroid therapy, densito-metric evidence of osteoporosis, the ready availability of a bone measurement. The increased persistence to osteoporosis treatment observed in patients on chronic NSAID is possibly explained by the high prevalence of vertebral fracture among these patients $\left(\chi^{2}=17.1 ; \mathrm{p}<0.001\right)$. The use of benzodiazepines and gastro-protective agents was a predictor of poor treatment persistence, possibly in relationship with the underlying co-morbidity. Somewhat surprisingly, age was not a predictive factor, even when analyzed individually in the logistic regression analysis. This may be explained by the balancing of decreasing general adherence with advancing age and the increased motivation to treatment for the severity of the disease. We also evaluated treatment compliance among patients who did not discontinue therapy. The compliance was rather poor for CaVitD supplements, with only one-half of the patients taking $>80 \%$ of the prescribed doses, and, a sex expected, particularly high for HRT. Of 
Annals of International Medical and Dental Research

E-ISSN: 2395-2822 | P-ISSN: 2395-2814

Vol-8, Issue-2 | March-April 2022

DOI: 10.53339/aimdr.2022.8.2.22

Page no- 164-173 | Section- Research Article (Orthopedics)

relevance is the significantly greater treatment compliance for ALN OW therapy versus all other bisphosphonates. This indicates that this treatment regimen is associated not only to increased persistence but also to greater compliance. Treatment compliance was poorer in patients suffering gastro-intestinal problems, but was enhanced by the ready availability of bone measurements with values within the range of osteoporosis. This is in agreement with previous reports that showed that those who understood their bone densitometry results were more likely to fill their prescriptions. [8,28,29] Even though the global adherence to treatment (i.e.: both persistence and compliance) was strongly related to the type of prescriber, this seems to have been driven mostly by the strong interaction between prescriber and nature of type of treatment, adherence remained significantly poorer for patients of GPs and Orthopaedic surgeons, primarily due to a lack of adequate

\section{REFERENCES}

1. Berg JS, Dischler J, Wagner DJ, Raia JJ, PalmerShevlin N. Medication compliance: a healthcare problem. Ann Pharmacother. 1993 Sep;27(9 Suppl):S1-24.

2. Miller NH. Compliance with treatment regimens in chronic asymptomatic diseases. Am J Med. 1997;102(2A):43-9. doi: 10.1016/s0002-9343(97)004671.

3. Sung JC, Nichol MB, Venturini F, Bailey KL, McCombs JS, Cody M. Factors affecting patient compliance with antihyperlipidemic medications in an HMO population. Am J Manag Care. 1998;4(10):1421-30.

4. Coronary Drug Project Research Group. Influence of adherence to treatment and response of cholesterol on mortality in the coronary drug project. N Engl J motivation. This is in agreement with a recent study showing that patients of GPs were more likely to discontinue their medications than the patients of internists. [29]

\section{CONCLUSIONS}

In conclusion, the type of treatment given was the most important factor of both persistence and compliance to treatment in this large study of Bangladeshi osteoporotic women, with a clear preference for ALN OW. Treatment adherence was notably low for CaVitD, underlining the need to develop innovative methods of giving supplements, particularly vitamin D. The major causes for treatment termination were adverse effects and a lack of desire, with patients with severe and welldocumented osteoporosis having the highest treatment adherence. The clinical implications of this form of treatment observance, as well as the financial consequences, require further investigation.

Med. 1980;303(18):1038-41. doi: 10.1056/NEJM198010303031804.

5. Schweizer RT, Rovelli M, Palmeri D, Vossler E, Hull D, Bartus S. Noncompliance in organ transplant recipients. Transplantation. 1990;49(2):374-7. doi: 10.1097/00007890-199002000-00029.

6. Cramer JA, Glassman M, Rienzi V. The relationship between poor medication compliance and seizures. Epilepsy Behav. 2002;3(4):338-342. doi: 10.1016/s1525-5050(02)00037-9.

7. Zygmunt A, Olfson M, Boyer CA, Mechanic D. Interventions to improve medication adherence in schizophrenia. Am J Psychiatry. 2002;159(10):165364. doi: 10.1176/appi.ajp.159.10.1653.

8. Tosteson AN, Grove MR, Hammond CS, Moncur MM, Ray GT, Hebert GM, et al. Early discontinuation of treatment for osteoporosis. Am J Med. 2003;115(3):209-16. doi: 10.1016/s00029343(03)00362-0. 
Annals of International Medical and Dental Research E-ISSN: 2395-2822 | P-ISSN: 2395-2814

Vol-8, Issue-2 | March-April 2022

DOI: 10.53339/aimdr.2022.8.2.22

Page no- 164-173 | Section- Research Article (Orthopedics)

9. Segal E, Tamir A, Ish-Shalom S. Compliance of osteoporotic patients with different treatment regimens. Isr Med Assoc J. 2003;5(12):859-62.

10. Turbí C, Herrero-Beaumont G, Acebes JC, Torrijos A, Graña J, Miguélez R, et al. Compliance and satisfaction with raloxifene versus alendronate for the treatment of postmenopausal osteoporosis in clinical practice: An open-label, prospective, nonrandomized, observational study. Clin Ther. 2004;26(2):245-56. doi: 10.1016/s0149-2918(04)900239.

11. Sewerynek E, Dabrowska K, Skowrońska-Jóźwiak E, Zygmunt A, Lewiński A. Compliance with alendronate 10 treatment in elderly women with postmenopausal osteoporosis. Endokrynol Pol. 2009;60(2):76-81.

12. McCombs JS, Thiebaud P, McLaughlin-Miley C, Shi J. Compliance with drug therapies for the treatment and prevention of osteoporosis. Maturitas. 2004;48(3):271-87.

doi: 10.1016/j.maturitas.2004.02.005.

13. Hamilton B, McCoy K, Taggart H. Tolerability and compliance with risedronate in clinical practice. Osteoporos Int. 2003;14(3):259-62. doi: 10.1007/s00198-002-1370-3.

14. Yood RA, Emani S, Reed JI, Lewis BE, Charpentier M, Lydick E. Compliance with pharmacologic therapy for osteoporosis. Osteoporos Int. 2003;14(12):965-8.

15. Caro JJ, Ishak KJ, Huybrechts KF, Raggio G, Naujoks C. The impact of compliance with osteoporosis therapy on fracture rates in actual practice. Osteoporos Int. 2004;15(12):1003-8. doi: 10.1007/s00198-004-1652-z.

16. Papaioannou A, Ioannidis G, Adachi JD, Sebaldt RJ, Ferko N, Puglia $\mathrm{M}$, et al. Adherence to bisphosphonates and hormone replacement therapy in a tertiary care setting of patients in the CANDOO database. Osteoporos Int. 2003;14(10):808-13. doi: 10.1007/s00198-003-1431-2.

17. Kayser J, Ettinger B, Pressman A. Postmenopausal hormonal support: discontinuation of raloxifene versus estrogen. Menopause. 2001;8(5):328-32.

18. Ettinger B. Alendronate use among 812 women: prevalence of gastrointestinal complaints, noncompliance with patient instructions, and discontinuation. Journal of Managed Care Pharmacy. 1998;4(5):488-92.
19. Kotzan JA, Martin BC, Wade WE. Persistence with estrogen therapy in a postmenopausal Medicaid population. Pharmacotherapy. 1999;19(3):363-9. doi: 10.1592/phco.19.4.363.30935.

20. Recker RR, Gallagher R, MacCosbe PE. Effect of dosing frequency on bisphosphonate medication adherence in a large longitudinal cohort of women. Mayo Clin Proc. 2005;80(7):856-61. doi: 10.4065/80.7.856.

21. Faulkner DL, Young C, Hutchins D, McCollam JS. Patient noncompliance with hormone replacement therapy: a nationwide estimate using a large prescription claims database. Menopause. 1998;5(4):226-9.

22. Cole RP, Palushock S, Haboubi A. Osteoporosis management: physicians' recommendations and womens' compliance following osteoporosis testing. Women Health. 1999;29(1):101-15. doi: 10.1300/J013v29n01_08.

23. Claxton AJ, Cramer J, Pierce C. A systematic review of the associations between dose regimens and medication compliance. Clin Ther. 2001;23(8):1296310. doi: 10.1016/s0149-2918(01)80109-0.

24. Simon JA, Lewiecki EM, Smith ME, Petruschke RA, Wang L, Palmisano JJ. Patient preference for onceweekly alendronate $70 \mathrm{mg}$ versus once-daily alendronate $10 \mathrm{mg}$ : a multicenter, randomized, open-label, crossover study. Clin Ther. 2002;24(11):1871-86. doi: 10.1016/s01492918(02)80085-6.

25. Kendler D, Kung AW, Fuleihan Gel-H, González González JG, Gaines KA, Verbruggen N, et al. Patients with osteoporosis prefer once weekly to once daily dosing with alendronate. Maturitas. 2004;48(3):243-51. 10.1016/j.maturitas.2003.12.012.

26. Weiss M, Vered I, Foldes AJ, Cohen YC, ShamirElron Y, Ish-Shalom S; Israeli Alendronate OW Study Group. Treatment preference and tolerability with alendronate once weekly over a 3-month period: an Israeli multi-center study. Aging Clin Exp Res. 2005;17(2):143-9. doi: 10.1007/BF03324587.

27. Lemay A. The relevance of the Women's Health Initiative results on combined hormone replacement therapy in clinical practice. J Obstet Gynaecol Can. 2002;24(9):711-5. doi: 10.1016/s1701-2163(16)30326-7.

28. Pressman A, Forsyth B, Ettinger B, Tosteson AN. Initiation of osteoporosis treatment after bone 
Annals of International Medical and Dental Research

E-ISSN: 2395-2822 | P-ISSN: 2395-2814

Vol-8, Issue-2 | March-April 2022

DOI: 10.53339/aimdr.2022.8.2.22

Page no- 164-173 | Section- Research Article (Orthopedics)

mineral density testing. Osteoporos Int. 2001;12(5):337-42. doi: 10.1007/s001980170099.

29. Pickney CS, Arnason JA. Correlation between patient recall of bone densitometry results and subsequent treatment adherence. Osteoporos Int. 2005;16(9):1156-60. doi: 10.1007/s00198-004-1818-8.
Source of Support: Nil, Conflict of Interest: None declared 